\title{
'If Ya Wanna End War and Stuff, You Gotta Sing Loud'-A Survey of the Provisional Agreement between FARC and Colombia on Illicit Drugs
}

\section{Si desea que la guerra termine, hay que decirlo en voz alta: Un estudio del Acuerdo provisional entre las FARC y Colombia sobre drogas ilícitas}

\author{
Francesco Seatzu ${ }^{1}$ \\ Università degli Studi di Cagliari (Italia)
}

Recibido: 12-11-15

Aprobado: 23-01-16

\begin{abstract}
Although still neglected in legal writings, the 2014 agreement on illicit drugs between the FARC and the Colombian Government deserves attention for a number of reasons, including that it was conceived as an essential part of the broader strategy for peace in Colombia, as well as because of its aim of eradicating illicit crops. Starting with some remarks on the Colombian 'drug war' and the policy and legal arguments for classifying the Colombian armed conflict as a non-international armed conflict (NIAC), the paper will then proceed with an analysis of the main reasons behind the drafting of a partial agreement on illicit drugs between the FARC and Colombia in 2014. Next, the paper will address the relevant sections and enforcement mechanisms for putting the provisions of the agreement into effect. An assessment of how the 2014 agreement has addressed the issue of drug trafficking and the issues concerning drug related crimes will also be considered. The paper will conclude with the lessons to be drawn from the new Agreement on illicit drugs.
\end{abstract}

Key-words: illicit drugs, FARC and Colombia, non-international armed conflict (NIAC), peace process, illicit crops, human rights, war on drugs, drug trafficking, Latin America.

\footnotetext{
${ }^{1}$ (fseatzu@unica.it) Professor of International Law. El presente estudio se enmarca dentro del proyecto de investigación: "Las Respuestas del Derecho Internacional y Europeo a los Nuevos Riesgos y Amenazas Contra la Seguridad Humana" (RASEGUR), Plan Nacional de I+D+I (Ref.: DER2015-65906-P).
} 


\section{Resumen}

Aunque todavía es un tema descuidado por la doctrina, el Acuerdo de 2014 sobre las drogas ilícitas entre el Gobierno de Colombia y las FARC, merece atención por muchas razones, incluyendo el que fue concebido como una parte esencial de una estrategia más amplia para la paz en Colombia, así como por su objetivo de erradicar los cultivos ilícitos. Se parte de algunas observaciones sobre la "guerra contra las drogas 'de Colombia y la política y los argumentos jurídicos para clasificar el conflicto armado en Colombia como un conflicto armado no internacional. Seguidamente se hace un análisis de las principales razones que hay detrás de la elaboración de un acuerdo parcial sobre las drogas ilícitas entre las FARC y Colombia en 2014. A continuación, este trabajo se dirige a los mecanismos de aplicación para poner que sus disposiciones entren en vigor. Se hace, igualmente, una evaluación de la forma en que el Acuerdo de 2014 ha abordado la cuestión del tráfico de drogas y también se examinan las cuestiones relativas a los delitos relacionados con las drogas. El trabajo concluye con las lecciones que caben extraer del nuevo Acuerdo sobre las drogas ilícitas.

Palabras-clave: drogas ilícitas, FARC y Colombia, los conflictos armados sin carácter internacional, proceso de paz, derechos humanos, guerra contra las drogas, el tráfico de drogas, America Latina.

'There is no question today that peace and drugs are closely intertwined and that the solution of one problem hinges on the other'.

Francisco E. Thoumi

\section{Introduction}

The recent adoption of the partial agreement on illicit drugs reached at the meetings being held in Havana between the Revolutionary Armed Forces of Colombia, the FARC, and the Colombian Government marked a step by the Contracting Parties towards the complete elimination of both coca and drug trafficking in Colombian territory. The illegal drug economy in Colombia has grown significantly over the last few decades, to the point of producing, inter alia, a fearsome concentration of land ownership by drug traffickers in what is referred to as Colombia's 'counter-land reform', as a result of the accumulation of illegal funds ${ }^{2}$. Existing domestic laws in Colombia, such as Law no. 30 of 1986 known as the 'National Narcotics Statute' (Estatuto Nacional de

2 See e.g. Bojan Dobovšek, 'Understanding the Colombian Civil War', (2010) Review of International Affairs, pp. 23-47.

Araucaria. Revista Iberoamericana de Filosofia, Política y Humanidades, año 18, n 36. Segundo semestre de 2016. Pp. 373-389. ISSN 1575-6823 e-ISSN 2340-2199 doi: 10.12795/araucaria.2016.i36.16 
Estupefacientes - ENE), purely a tool of control and repression without any preventive and rehabilitative purposes, and Decree no. 1188 of 1974 which increased the sanctions for trafficking and criminalized use, have appeared unequal to the task of eradicating this vicious commerce ${ }^{3}$.Awakened to the necessity for concerted and more effective action to rein in the drug cartels, the Colombian Government and the FARC rebels began work in 2010 on an international agreement that would establish a set of guidelines to be applied by the two parties in suppressing illicit trafficking and achieving the enforcement of illegal crop substitution projects.

Adopted as part of a wider strategy for peace and at the fiftieth anniversary of the start of FARC's war against the Colombian Government in May 2014, the provisional agreement on illicit drugs between FARC rebels and the Colombian Government is aimed at establishing a new legal framework for the complete eradication of both drug trafficking and coca crops ${ }^{4}$. Explicitly recognizing that illicit trafficking is 'an international criminal activity', the Agreement introduces a different treatment for the growers of natural raw components for drugs from that of the criminal economic entities involved in the different steps of the illicit drug trade. It thus marks a path that begins with participation processes for local collectivities to make a commitment to the state to substitute illicit crops and refrain from participating in the trade of raw components derived from such crops. All producing collectivities - regardless of whether they approve or disapprove of crop replacement- will have their illicit crops eliminated, with the elimination being achieved either by the collectivities themselves or by public bodies established for this purpose. In addition to this, the Agreement also commits the Colombian Government to enacting measures so that globalcapitalistic countries, in particular the United States and the EU countries, will convert to policies to cut off demand, address use from the perspective of public health, and concentrate on fundamental rights. This is implicit in the idea, explicitly indicated in the Joint Communiqué issued on 16 May 2014, that: 'There won't be any solution to the problem of illicit drugs without the express commitment of the U.S. Government with a definitive change in their failed policy called war on drugs'.

Unlike the United Nations Convention Against Illicit Traffic in Narcotic Drugs and Psychotropic Substances, which is one of the most far-reaching tools ever adopted in the sector of international criminal law, the 2014 Agreement between the FARC

\footnotetext{
${ }^{3}$ Amplius Rodrigo Uprimny Yepes and Diana Esther Guzmán, 'Drug policy and the prison situation in Colombia', available at: http://druglawreform.info/images/stories/documents/Systems Overload/Colombia-en.pdf; T. Chantal, 'Disciplining Globalization: International Law, Illegal Trade, and the Case of Narcotics' (2003) Cornell Law Faculty Publications. Paper 1089, available at: http:// scholarship.law.cornell.edu/facpub/1089

${ }^{4}$ See Gillian Higgins, 'Peace Agreement Reached Between Colombian Government and FARC', available at: (also recalling that: 'While it is not in the text of the accord, President Juan Manuel Santos said that the sides have agreed to sign a final accord within the next six months').
} 
and Colombia neglects to approach the issue of drug trafficking in a efficient and operative way. Indeed, the language of this Agreement is rather unclear and opaque, as it fails to clarify the meaning and scope of such core expressions and notions as 'the problem of illicit drugs', 'the fight against organised crime', 'the strategy to combat asset laundering', and 'state control over the trade in inputs and precursor chemicals'. For these and other reasons, such as the wording that 'If we understand drug cartels as mafias that manage international trafficking routes, then the FARC is not the big cartel that the authorities make them out to be' ${ }^{5}$, the Agreement can only be seen as a contribution of little significance in the battle against illicit substances.

After some remarks on the Colombian drug war, on the policy and legal arguments for classifying the Colombian armed conflict as a non-international armed conflict (NIAC), and on the reasons leading up to the drafting of an international agreement on illicit drugs between the FARC and Colombia in 2014, this paper briefly reviews the most important terms of this provisional agreement, from an international legal perspective. As one of the biggest producers of psychotropic substances and narcotic drugs on the globe, Colombia has achieved broad experience in developing law enforcement instruments against drug cartels and drug traffickers, including FARC rebels. But this experience does not arise from the final text of the Agreement. However, most of the provisions of the 2014 Agreement reflect regulatory approaches and devices already present both in the international drug control system and in the repressive drug policies of the last decades of the twentieth century in Latin America (though not in the most recent OAS Position on Drugs) ${ }^{6}$. For this and other reasons, the Agreement between the FARC and Colombia, which is based on prohibition, does not consider the significant amount of progress achieved in processes, which currently constitutes a critical mass towards a regulation set-up, to use Ricardo Vargas's own words? ${ }^{7}$. These processes (again to use Ricardo Vargas's own words) include the drafting of new operative core terms paralleling elimination of drug crops, prohibition and enforcement, as well as the drafting of harm reduction schemes based on the idea that psychotropic substances and narcotic drugs must be accepted as a reality to be lived with, while avoiding or reducing the harm that psychotropic substances and drugs can cause to users and public health ${ }^{8}$.

\footnotetext{
5 'Las FARC y las drogas', El Tiempo, 27 February 2014, http:/www.eltiempo.com/opinion/columnistas/ gustavoduncan/las-farc-y-las-drogas-gustavo-duncan-columnista-el-tiempo- 13569875-4 (last accessed 21 October 2015), as quoted by John Otis, 'The FARC and Colombia's Illegal Drug Trade', available at: https:// www.wilsoncenter.org/sites/default/files/Otis_FARCDrugTrade2014.pdf (last accessed 4 November 2015).

${ }^{6}$ On this topic, see M. Speck, 'The OAS Position on Drugs: A (Gradual) New Approach', available at: http://blog.crisisgroup.org/latin-america/2013/06/21/the-oas-position-on-drugs-a-gradual-new-approach/

See Ricardo M. Vargas, 'Drugs, armed conflict and peace. How does the agreement on drugs between the government and the FARC help to put an end to the armed conflict in Colombia?', (2014) 42 Drug Policy Briefing, available at: https://www.tni.org/files/download/dpb_42_eng_072014.pdf

${ }^{8}$ See Ricardo M. Vargas, op. ult. cit.
} 


\section{Background Information on the Colombian 'Drug War'}

Since 1964, Colombia has experienced a low-intensity asymmetric war in which the Colombian Government has fought against several 'bandas criminales' (criminal gangs) also known as BACRIM groups, left-wing guerrillas, well-organized paramilitary groups such as the Revolutionary Armed Forces of Colombia, Latin America's oldest and largest guerrilla army known as the FARC, and the National Liberation Army (ELN), which are closely linked with drug trafficking. Since the beginning of this conflict, the United States has militarily assisted the Colombian Government in the battle against those guerrilla movements and against drug traffickers themselves ${ }^{10}$. One example of this assistance is the plan of cooperation between the United States and Colombia, called Plan Colombia: Plan for Peace, Prosperity, and the Strengthening of the State (usually referred to as 'Plan Colombia'), launched in 1999. As has already been observed by others, 'Plan Colombia' represented a new approach to cooperation against drug trafficking ${ }^{11}$.

This is evident if one considers that, since that time, the United States has treated the fight against drug traffickers in Colombia and elsewhere as essentially a police issue, supplying equipment and other aid to the police for counternarcotics efforts. However, since the early 2000s, the United States' approach has been to provide this assistance directly to the Colombian Government. Even more significantly, in addition to being militarized (the US shift to supporting the armed forces rather than the police), the fight against drug traffickers has also begun to privatize. The US Departments of State and Defense have contracted private military and security companies (PMSCs) in particular to offer logistics support for reconnaissance airplanes and maintain an up-to-date intelligence database.

Of special relevance to our investigation is the FARC's participation in Colombia's illegal drug trade. In this regard, it is worth stressing that the FARC has long defended its practice of boosting coca cultivation and then taxing drug

\footnotetext{
${ }^{9}$ See e.g. Bruce M. Bagley, 'Colombia and the War on Drugs', available at: https://www. foreignaffairs.org/articles/bolivia/1988-09-01/colombia-and-war-drugs (last accessed 4 November 2015); C. Voelkel, 'Five Common Misunderstandings of War and Peace in Colombia, Crisis Group', available at: http://blog.crisisgroup.org/latin-america/2012/10/08/five-common-misunderstandingsof-war-and-peace-in-colombia/ (last accessed 5 November 2015).

${ }^{10}$ See e.g. P. Burbidge, 'Justice and Peace ? - The Role of Law in Resolving Colombia's Civil Conflict', (2008) 3 International Criminal Law Review, p. 559 ff.

${ }^{11}$ Amplius L. W. Rosen, 'International Drug Control Policy: Background and U.S. Responses', available at: (also stressing that 'Plan Colombia' was intended to be a six-year plan, concluding in 2005, to end the country's decades-long armed conflict, eliminate drug trafficking, and promote economic and social development. The plan aimed to curb trafficking activity and reduce coca cultivation in Colombia by $50 \%$ over six years. In support of Plan Colombia and its follow-up programs, the US government spent more than $\$ 8$ billion in security and development assistance between FY2000 and FY2011, including both civilian and military counterdrug support efforts).
} 
producers for defending their crops on the grounds that peasants in remote zones have no real alternatives for living their existence. Control over coca cultivation in Colombia aided the FARC in expanding its social base. Moreover, it has also led the Colombian Defence Minister, Juan Carlos Pinzón, to note that the FARC was involved in drug trafficking 'at every level'. Nevertheless, the FARC is not yet involved in the most lucrative downstream features of the drug trade: retail distribution in consumer countries. In other words, within the illegal drug industry's division of labour, the FARC's strength lies in retaining control over coca growers in southern Colombia, and in the defence its affiliates can offer to drug traffickers through its status as the last remaining illegal armed entity with a national standing in Colombia.

\section{Policy and Legal Arguments for Classifying the Colombian Drug War as a NIAC}

Our starting point here is that the Colombian conflict can be characterized as an armed conflict due to the presence of numerous guerrilla movements and paramilitary groups with responsible command controlling some portions of Colombian territory, and to the intensity of violence against civilians and the Colombian state. In particular, the intensity of violence justifies this statement. This is because some important triggers considered in the classification of an armed conflict are its intensity, duration and scope ${ }^{12}$.

Looking at the Colombian situation, the so called Colombian drug war, through the international humanitarian law (IHL)'s most classical distinction of armed conflicts into 'international armed conflict (IAC)' and 'non-international armed conflict (NIAC)', it is not difficult to conclude that the situation in Colombia resembles a NIAC ${ }^{13}$. More precisely, this situation resembles a specific type of NIAC, that is 'internal armed conflict, including one or more foreign interventions ${ }^{14}$. This conclusion -which is important because whether

${ }^{12}$ See e.g. Alex G. Peterson, Order out of Chaos: Domestic Enforcement of the Law of Internal Armed Conflict, 171 Mil. L. Rev. 1 (2002), pp. 9-10; Sylvain Vité, Typology of Armed Conflicts in International Humanitarian Law: Legal Concepts and Actual Situations, 91 INT'L REV. OF THE RED CROSS 69, 70 (2009), http://icrc.org/eng/assets/files/other/irrc-873-vite.pdf.

13 On this distinction, see e.g. Carina Bergal, 'The Mexican Drug War: The Case for a NonInternational Armed Conflict Classification', (2011) 34 Fordham Int'l L.J., p. 1047 ff (also recalling that: 'Although NIAC was not regulated prior to the Geneva Conventions of 1949, Common Article 3 served as the basis from which to resolve the meaning of NIAC under IHL.'.)

${ }^{14}$ Incidentally, it is worth recalling that though the possibility of internationalizing a conflict is widely accepted in international jurisprudence, the same jurisprudence remains divided on the issue of what degree of control by one state over the parties acting internally in another state is required to internationalize a NIAC. See e.g. A. Perret, above no. 15 (stressing that prior to Tadić, the International Court of Justice (ICJ) did not attribute the acts of the contras - the various rebel groups opposing Nicaragua's Sandinista National Liberation Front - to the United States, because the control the state exercised over them was not comparable to the control that the United States would exercise over its 
or not an armed conflict is international or non-international is fundamental for establishing the extent to which international humanitarian law (IHL) applies to a situation ${ }^{15}$ - is suggested by the fact that the privatization of cooperation between the United States and Colombia, the so-called 'Plan Colombia', which allowed the United States Government to fight against drug cartels in Colombia, worked as a source of internationalization of the Colombian conflict $^{16}$. This has been particularly evident since the early 2000s, when the US Departments of State and Defense hired a wide number of private military and security companies (PMSCs) to lead activities to aid the Colombian police and army ${ }^{17}$. Moreover, that the Colombian conflict is to be classified as a de jure armed conflict to which international humanitarian law (IHL) applies is indirectly confirmed by the scope of the conflict between the Colombian authorities and domestic drug traffickers, which has obliged the Colombian Government to respond not only with law enforcement but also with military forces in an escalating conflict. ${ }^{18}$ In fact, the nature of both the Colombian war and the corresponding military response has transformed this conflict from a simple criminal activity to an armed conflict (that is a NIAC), subject to the law governing armed conflicts, and the accompanying human rights provisions in particular. This is despite the fact that, according to a traditional communis opinio, the laws of armed conflicts were not applicable to a NIAC unless an established state recognized the belligerency of the non-state entity. ${ }^{19}$ But this approach radically changed over time, since the international community

own state actors. As a result, the ICJ held that the Nicaraguan armed conflict was not internationalized and instead remained a NIAC).

${ }^{15}$ In most circumstances, the only IHL applicable in a NIAC is Common Article 3 of the Geneva Conventions, whereas all of IHL applies in a NIAC.

${ }^{16}$ See Phil Williams, 'Transnational criminal organisations and international security', (1994) 36 Survival: Global Politics and Strategy, pp. 96-113.

17 PMSCs can be defined as: "[C]orporations offering security, defence and/or military services to states, international organizations, nongovernmental organizations, and private companies and/ or armed groups. These services include armed guarding and protection of persons and objects or buildings, maintenance and operation of weapons systems, prisoner detention and interrogation, intelligence, risk assessment and military research analysis, as well as advice to or training of local forces and security personnel'. See Francesco Francioni, Natalino Ronzitti, 'Introduction', in Francesco Francioni, Natalino Ronzitti (eds.), War by Contract: Human Rights, Humanitarian Law, and Private Contractors, Oxford: OUP, 2011, p. 1.

${ }_{18}$ Amplius T. Dunninga, L. Wirpsa, 'Oil and the political economy of conflict in Colombia and beyond: a linkages approach' (2004) 9 (1) Geopolitics, pp. 81-108; Angel Rabasa, Peter Chalk, Colombian Labyrinth: The Synergy of Drugs and Insurgency and Its Implications for Regional Stability, RAND: Pittsburgh, 2001, pp. 1-6.

${ }^{19}$ Further discussion and references on this issue can be found in S. Sivakumaran, The Law of NonInternational Armed Conflict, Oxford: OUP, 2012, PP. 155-212; Marco Sassòli, The Role of Human Rights and International Humanitarian Law in New Types of Armed Conflicts, in Orna Ben-Naftali (ed.), International humanitarian law and international human rights law, Oxford: OUP, 2011, p. 19 ff; M. Happold, 'International Humanitarian Law and Human Rights Law', in Christian Henderson and Nigel White (eds.), Research Handbook on International Conflict and Security Law, Edward Elgar, 2012, also available at SSRN: http://ssrn.com/abstract=2065974

Araucaria. Revista Iberoamericana de Filosofía, Política y Humanidades, año 18, n 36. Segundo semestre de 2016. Pp. 373-389. ISSN 1575-6823 e-ISSN 2340-2199 doi: 10.12795/araucaria.2016.i36.16 
accepted that: '[w]hat is inhumane, and consequently proscribed, in international wars, cannot but be inhumane and inadmissible in civil strife' ${ }^{20}$ In other words, the laws of armed forces evolved and enacted a more humanistic attitude, and international humanitarian law is currently the main law utilized when referring to armed conflicts ${ }^{21}$.

However, a very different conclusion, namely the classification of the Colombian conflict as a pure NIAC, could be inferred from the fact that PMSCs contracted by the United States supplied services such as fumigation of illegal coca cultivation and intelligence without direct and strict control by the United States Government ${ }^{22}$. However, there are numerous cases of a US PMSC's de facto participation in the Colombian internal conflict ${ }^{23}$. This is despite the fact that in purely legal terms, US PMSCs are not to be involved in hostilities, since the US Congress has forbidden all activities involving close and direct participation in the Colombian conflict ${ }^{24}$. In this regard, it is sufficient to recall, as exemplary of this de facto participation, the activities of DynCorp. The US State Department contracted DynCorp to fumigate the illegal cultivation of coca plants in southern and central Colombia. Although fumigation comprised the main content of the contract between DynCorp and the US State Department, the presence of DynCorp contractors in the combat helicopters that generally accompanied the planes that dropped the glyphosate, and their participation in repelling attacks, was significant ${ }^{25}$. This is confirmed by statistics: between 2001 and 2002 (just one year after the start of DynCorp's fumigation contract), nearly 10 aircraft attacks per month occurred, increasing in 2003 to reach a peak of 70 attacks per month ${ }^{26}$. The use of force inherent in these helicopter missions led to the conclusion that these PMSCs were involved

20 See Prosecutor v. Tadic, Case No. IT-91-1-AR72I, Decision on the Defence Motion for Interlocutory Appeal on Jurisdiction, p. 119 (ICTY Oct. 2, 1995).

21 See e.g. A. G. Peterson, above n. 8, p. 13.

22 See M. Boysen, Private Military Firms as Instruments of U.S. Foreign Policy: The Case of Columbia, Master's Thesis, 2007, ch. I and II.

${ }^{23}$ Amplius R. Majewski, 'Cocaine Blues: The Cost of Democratization under Plan Colombia', in M. Forte (ed.), Force Multipliers: The Instrumentalities of Imperialism, Alter Press, 2015, p. $125 \mathrm{ff}$.

${ }^{24}$ See e.g. A. Perret, The role of the inter-American system of human rights in the regulation of private military and security companies (PMSCs) in Latin America, EUI PhD theses, 2014, available at: http://hdl.handle.net/1814/33870 (last accessed 4 November 2015); R. Majewski, above n. 21, p. 125 ff.

25 See F. Mathieu, N. Dearden, 'Corporate Mercenaries: The Threat of Private Military \& Security Companies' (2007) 34 (114) Review of African Political Economy, pp. 744-755; A. Leander, 'The Power to Construct International Security: On the Significance of Private Military Companies', (2005) 33 Journal of International Studies, pp. 803-825; K McCallion, 'War for Sale! Battlefield Contractors in Latin America \& the 'Corporatization' of America's War on Drugs' (2005) 36 (2/3) The University of Miami Inter-American Law Review, pp. 317-353.

${ }^{26}$ Amplius K. Penhaul, 'Americans Blamed in Colombia Raid', SAN FRANCISCO CHRON., 15 June 2001, available at: http://sfgate.com/news/article/Americans-blamed-in-Colombia-raid-2910509.php, as quoted by A Perret, 'Privatization of the War on Drugs in Mexico and Colombia. Limiting the Application of Humanitarian Law and Endangering Human Rights', (2012-2013) Interdisciplinary Journal of Human Rights Law, p. 55, note 45.

Araucaria. Revista Iberoamericana de Filosofía, Política y Humanidades, año 18, $\mathrm{n}^{\circ} 36$. Segundo semestre de 2016. Pp. 373-389. ISSN 1575-6823 e-ISSN 2340-2199 doi: 10.12795/araucaria.2016.i36.16 
in the Colombian conflict. Nevertheless, though it is clear in the Colombian context that PMSCs have taken part in the hostilities, it is harder to demonstrate the second requirement: that the PMSCs were acting as agents of their home country's government. Although this is difficult, the International Law Commission (ILC) Draft Articles on Responsibility of States for Internationally Wrongful Acts offers some guidance in ascertaining the relationship between a PMSC and its home country ${ }^{27}$.

\section{Why an Agreement on Illicit Drugs Between the FARC and Colombia?}

One might be tempted to answer this question by asking why Colombia, unlike the vast majority of the states of the world, is not part of the International drug control system. In particular, unlike Peru and Bolivia, Colombia has only signed, but has not ratified, the 1988 U.N. Convention on Illicit Drug Trafficking and Psychotropic Substances (C.I.D.T.) ${ }^{28}$.While there are obvious reasons for this at first, others are less obvious and are to be reported. Of course, there is the obvious difficulty for a top drug trafficking country like Colombia to adhere to the prohibition-oriented UN drug control system $^{29}$. This is evident if one considers that Colombia is the major illicit producer and supplier of cocaine and marijuana to the United States and other drug markets. Again, this is also clear if one considers that, unlike Bolivia and Peru, which grow the world's supply of the coca leaf crop, Colombia synthesizes the natural coca leaf into cocaine and provides transport services.

${ }^{27}$ According to the ILC, there are certain circumstances in which the wrongful act of a foreign organ, such as a PMSC, can be attributed to its home state. These circumstances arise when the foreign organ continues to act as part of, and under the auspices of, the home state, and when there is no real functional link established with the beneficiary state. In the context of the Colombian conflict, wrongful conduct by US PMSCs may be attributable to the United States government if the PMSCs are acting in the service of the United States government, rather than the Colombian government. On this issue, see e.g. A Perret, above n. 22, p. $54 \mathrm{ff}$.

28 Adopted by consensus at an international conference of 106 states in Vienna in December 1988, the Illicit Trafficking Convention is intended to establish a new international legal regime for combating international drug trafficking. Explicitly recognizing in the preamble that illicit trafficking is 'an international criminal activity', it requires that each signatory state establish as criminal offenses under its domestic law a comprehensive list of activities involved in or related to international drug trafficking. For commentary, see e.g. J. Gurule, 'The 1988 U.N. Convention Against Illicit Traffic in Narcotic Drugs and Psychotropic Substances - A Ten Year Perspective: Is International Cooperation Merely Illusory?' (1988) 2 Fordham International Law Journal, p. 74 ff; D. HEILMANN, 'The international control of illegal drugs and the U.N. treaty regime: Preventing or causing human rights violations?', available at: http:// works.bepress.com/daniel_heilmann/1 (last accessed 6 November 2015).

${ }_{29}$ See A. Castro Escudero, 'El narcotráfico en Colombia', available at: http://www.gestiopolis. com/el-narcotrafico-en-colombia (last accessed 14 October 2015) (stressing that Colombia has acted more aggressively than most of the signatories of the 1988 Vienna Convention Against Illicit Traffic in Narcotic Drugs and Psychotropic Substances, by including chemicals and drug precursors that are freely traded in the rest of the world on the list of nationally controlled substances). 
More precisely, the cocaine base that is produced in Peru and Bolivia is exported through Colombia to the global drug markets.

But, having stated this, it would be wrong to affirm that the perplexities associated with the various criticisms of the United Nations and the drug control bodies for keeping the international drug system unchanged in face of fundamental rights breaches by the Contracting States in the so-called 'wars on drugs' had no influence on the drafting of the 2014 Agreement. In this regard, one may take as an example the Latin American Commission on Drugs and Democracy statement, according to which: 'the search for more efficient policies, rooted in the respect for human rights, implies taking into account the diversity of national situations and emphasizing prevention and treatment ${ }^{30}$. Moreover, one may recall that the adoption of UN drug treaties into internal law also brought some concerns in the eyes of the drafters of the 2014 Agreement, since some of society's most vulnerable collectivities were seriously affected by it, such as, for instance, drug addicts (who are vulnerable to discrimination) and farmers in developing countries (who grow illicit crops and generally have no economically sound alternative) ${ }^{31}$. Yet all this is far from surprising (at least if one considers that the prohibition approach of the UN drug control conventions has often led to the occurrence of serious and documented breaches of human rights in various countries). Self-evidently, this is mainly because the states that restrictively interpret their duties under the $\mathrm{UN}$ drug treaties tend to enforce laws that are beyond the treaty's requirements. However, having stated this, it must be kept in mind that the impact of the UN drug treaties on the internal policies on illicit drugs as a result of their implementation in the internal legal orders of the Contracting States was only one factor -although a considerable one- out of many. Things were further complicated, inter alia, by the fact that the international drug control framework currently faces a twofold problem: while on the one hand some countries operate, to the extent that human rights are breached, with repressive drug supervisory legislation and enforcement, other countries follow liberal drug policies that have the potential to run counter to the purposes of UN drug control. In other words, summing up, the international drug control system, being a prohibition framework focused on controlling the production of narcotic drugs and psychoactive substances considered harmful to public health, has over time developed side effects that were not taken into account (at least in their magnitude) when it was created, but must now be taken into consideration by the drafters of any drug treaty or statute.

${ }^{30}$ Drugs and Democracy: Toward a Paradigm Shift. Statement by the Latin. American Commission on Drugs and Democracy, available at: http://www.drogasedemocracia.org/Arquivos/declaracao ingles_site.pdf(last accessed 9 Nobember 2015).

${ }_{31}$ See e.g. D. Heilmann, 'International Control of Illegal Drugs and the U.N. Treaty Regime: Preventing or Causing Human Rights Violations', (2011) 19 Cardozo J. Int'l \& Comp. L., p. 237 ff. 
But can all this on its own explains the existence of the 2014 Agreement between Colombia and the FARC on illicit drugs? The answer is no, for a number of reasons. Firstly, it would otherwise be hard, if not impossible, to explain why the 2014 Agreement's main concerns are replacement of illegal crops, the subsequent elaboration of development programmes with the involvement of local collectivities, and the enforcement of drug consumption prevention actions, instead of the supervision of the trafficking of illegal narcotic substances from Colombia to the global drug markets (like the C.I.D.T. $)^{32}$. Second, it would be hard to understand why the suspension of aerial chemical spraying and reparations for its victims, the restructuring of the national health system and the extradition of narcotics traffickers are among the issues which remain to be resolved despite their importance in practise. Thirdly and lastly, it would be hard to understand why the abovenamed Agreement will likely have a minimal impact on the drug trade, since it fails to address the root causes of the illegal drug economy in Colombia.

It is this author's opinion that at least one more reason could also be advanced to explain the existence of the 2014 Agreement between Colombia and the FARC: the relationship between drugs and peace in Colombia ${ }^{33}$. This relationship is implicitly acknowledged by the inclusion of the subject of drugs on the agenda for the peace talks being held in Havana between FARC guerrilla leaders and the Colombian government. More precisely, it is implicitly acknowledged by the fact that issues of illicit crops, narcotic drug production and trafficking are among the major (and less undisputed) challenges for a sustainable peace in Colombia. Again, even before that, the relationship between peace and illicit drugs in Colombia is suggested by the circumstance that the Colombian Government and the FARC have been engaged in peace negotiations since 2012 and have thus far reached agreements on land reform, political participation, and illegal drugs. Moreover, that the relationship between peace and illicit drugs in Colombia can be of some use to explain the existence and contents of the 2014 Agreement between Colombia and FARC guerrilla leaders is indirectly confirmed by the formal qualification of this Agreement as a 'partial agreement', namely as a collateral agreement to the future and final

${ }^{32}$ On this issue, see Ricardo M. Vargas, above n. 6 (also stressing that the text of the 2004 Agreement that places an emphasis on the eradication of illegal coca crops and stipulates that coca growing communities must be allowed to participate in the planning and implementation of crop substitution programs leaves few doubts about its real aims and priorities).

${ }^{33}$ On the peace process in Colombia from an international legal perspective see C. Bernal-Pulido, 'Transitional justice within the framework of a permanent constitution: The case study of the legal framework for peace in Colombia', (2014) 3 (4) Cambridge Journal of International and Comparative Law, p. 1143; E. Maculan, 'The Colombian "Comprehensive System of Truth, Justice, Reparation and Non Repetition": A Holisic and Innovative Proposal', available at: https://aninternationallawblog. wordpress.com/2015/12/14/the-colombian-comprehensive-system-of-truth-justice-reparation-andnon-repetition-a-holistic-and-innovative-proposal/ (last accessed 18 Jauary 2016). 
peace treaty ${ }^{34}$. Furthermore, and more significantly, it is indirectly confirmed by the circumstance that 'a political settlement without the drugs issues as a key point in the negotiations agenda is inconceivable' ${ }^{35}$. Lastly, it is indirectly confirmed by the classification of the Colombian conflict as a NIAC, a conflict arising between a sovereign state and a non-state actor.

Rebus sic stantibus, it remains to be seen whether the Agreement between the Colombian Government and FARC guerrilla leaders on illicit drugs could operate as a useful tool for ending the 'war drug' in Colombia.

\section{Summary of Provisions}

As adopted, the 2014 Agreement calls upon the two Contracting Parties to enact specific enforcement measures to increase their ability to address illicit coca crops and prosecute those who are involved in drug trafficking across the Colombian borders. Such measures include setting up a specialized Truth Commission to investigate the global cartels of illicit drug dealers, award compensation to victims of aerial spraying with chemical agents, prompt suspension of aerial spraying with chemical agents, demilitarize the territories and anti-drug policies, identify, persecute and expropriate drug dealers' assets, enact special measures against corruption produced by narco-paramilitarism, and recognize the use of psychoactive drugs as a public health issue.

In addition, the Agreement prescribes recognizing and improving the licit uses of coca, poppy and marijuana, and imposes special protections on the producers of coca leaves and the users of illicit drugs. It is also demanded that the FARC and Colombia adopt effective measures to eradicate illicit cultivation of plants containing narcotic or psychotropic components, cooperate in eradicating illicitly cultivated crops, and enact measures aimed at ending or diminishing illicit demand.

Lastly, as part of the democratic reorganization of the Colombian state, and as a response to the obsolescence of the current institutions of anti-drug policy that focus on counterinsurgency approaches and are subordinated to US anti-drug policy, a new institutional regulation is foreseen to meet the purposes and actions included in the set of proposals elaborated by the FARC-

${ }^{34}$ See also Kyra Gurney, 'FARC, Colombia Govt Drug Agreement Doomed to Failure?', available at: http://www.insightcrime.org/news-analysis/farc-colombia-govt-drug-agreement-doomed-to-failure (last accessed 4 November 2015) (stressing that: 'While the partial agreement reached on illegal drugs serves as a promising sign that peace negotiations are moving forward, in the event of a final agreement ultimately being signed, the drug trade measures stipulated will likely prove difficult to enact').

${ }^{35}$ See M. Jelsma, 'Conflict, Sustainable Development, and the Illegal Drug Economy in Colombia: An Analysis of Trends and Policy Recommendations for a Peace Building Approach', available at: https://www.tni.org/sites/www.tni.org/files/koffjelsma_0.pdf (last accessed 5 November 2015). 
EP, regarding the fourth item on the Agenda, 'Solution to the problem of illicit drugs'. The development of the new institutions will be the responsibility of the 'Commission for the design and monitoring of a sovereign, democratic and participatory national anti-drug policy’.

\section{Addressing Illicit Crops}

Point 2 of the Agreement (also known as the second sub-proposal of the Joint Communiqué of 16 May 2014) requires developing and enforcing the 'National Program for the substitution of illicit uses of coca, poppy and marijuana crops'. The rationale behind this statement is clear and straightforward: the idea that the main reasons for the growth of the illicit traffic in coca leaf and marijuana are socioeconomic, and lie in the poverty of displaced persons from the countryside, planters, and indigenous groups. In more general terms, the rationale behind the underlying approach in point 2 is the perception that measures to reduce production in the initial phases of the drug chain will lead to a diminution in supply. This is consistent with the initially-agreed aim of finding 'a definitive solution to the problem of illicit drugs'.

To the contrary, less clear, and open to dispute, is why the territorial approach that the Agreement enacts is not based on an integrated view of the territory, but is reduced to the coca situation. This is particularly the case when one considers that point 2 also provides that: 'The policy for the substitution of the illicit uses of crops aims to favor an approach of comprehensive civil, political, economic, social, cultural and human rights over policy of interdiction or prohibition, persecution, stigmatization and criminalization', as well as: '... the improvement of the living conditions of workers of coca, poppy and marijuana crops'. Moreover, it is far from clear and understandable why the possibility of using land seized from drug cartels as a way to give farmers a more feasible alternative -for reasons of location, soil quality and access to markets- was not even contemplated in the Agreement/Joint Communiqué ${ }^{36}$.

These 'core' or 'covered' statements under point 2 are the cornerstone of the new Agreement, and are clearly linked to the FARC rebels' Marxist political designs of radically challenging imperialist capitalism in Colombia ${ }^{37}$. Many of the other provisions in the Agreement/Joint Communiqué, for instance those relating to the 'broadest possible amnesty' for the political crime of rebelling against the state and for the so called 'connected crimes' (but not for

\footnotetext{
${ }^{36}$ Amplius Ricardo Vargas, above n. 6.

37 The FARC is a Marxist group that originated in the 1970 s with the aim of taking over the government in Colombia by violence. On this issue, see e.g. Ari Chaplin, Chávez's Legacy: The Transformation from Democracy to a Mafia State (University Press of America, 2014), xxx.
} 
crimes against humanity, genocide, serious war crimes, hostage-taking or other serious privation of liberty, torture, forced displacement, forced disappearance, extrajudicial executions, or sexual violence) ${ }^{38}$ and to a good living for peasant communities and families, and the provisions on the prevalence of human rights with regard to the policies of substitution of illicit uses of crops, and on compensation and incentives for producing communities and workers, are keyed to these statements.

Closely linked to point 2, point 6 of the Agreement states that: 'Contracting Parties are required to take necessary steps to demilitarise territories and anti-drug policies'. This statement, which is in line with the FARC-EP's transformation into a legal political entity, is complemented by other statements concerning the non-intervention, autonomy and self-determination of antidrug policies. Moreover, and more significantly, it is complemented by the prescription (again in point 6) of a programme to decriminalize producers and workers, as well as narcotics consumers. From all this and other evidence, it may then be safely concluded that point 6 is a self-enforcing and self-executing provision. In fact, unlike the majority of other points in the Agreement/Joint Communiqué, point 6 is comprised largely of fully self-executing statements. Specially exemplary in this regard is the statement that foresees the end of the governmental strategies to bring a state presence to rural and conflicted areas, the so called 'National policy for territorial consolidation' (PNCRT) and 'Territorial consolidation plans' ${ }^{39}$.

\section{Addressing Drug Trafficking}

It has been correctly observed that the Agreement/Joint Communiqué has addressed the issue of drug trafficking in an extremely generalized manner. There is considerable evidence of this, but prominent here is the failure to provide for adequate mechanisms for the monitoring, detection, retrieval and confiscation of drug-related laundered funds and assets (perhaps with the sole notable exception of the 'Independent Commission of Truth on the transnational capitalist enterprise of drug-trafficking'). Other evidence concerns the absence of control measures to prevent drug traffickers from obtaining secure identity documents or counterfeiting them. Moreover,

38 On this issue, see in particular A. Kay, 'Peace Agreement Reached Between Colombian Government and FARC', available at: http://9bri.com/peace-agreement-reached-between-colombiangovernment-and-farc/ (last accessed 4 November 2015) (stressing, inter alia, that an amnesty law will specify the extent of this 'connectedness').

39 On the subject, see e.g. Claudia Sánchez-Bustamante, 'Territorial Consolidation in Colombia: the Right to have Territory and a Territory with Rights', available at: http://dialogo-americas.com/ en_GB/articles/rmisa/features/regional_news/2014/01/06/consolidacion-territorial (last accessed 21 October 2015). 
further evidence arises from the lack of appropriate budgetary funds for drug supervision and crime prevention in the Agreement/Joint Communiqué. Lastly, additional evidence may be found in the language of the Agreement/ Joint Communiqué, which is far too imprecise and vague, as it fails to clarify the meaning of such key expressions as 'the fight against organized crime', 'the strategy to combat asset laundering', 'state control over the trade in inputs and precursor chemicals', 'state control on capital flows, financial regulations and special audits', 'the special measures and actions against corruption produced by narco-paramilitarism' and, lastly, the reiteration that asset forfeiture procedures will be 'effectively applied'40.

Similar considerations also apply, Mutatis mutandis, to the 'Special Jurisdiction for Peace' ('SJP'), which is to be composed by two sections or chambers (the Tribunal for Peace and the Chambers of Justice). Although it is clear that this jurisdiction will operate as a separate jurisdiction not subject to normal rules, it is not clear whether it will be a temporary body in Colombia's justice system. Unfortunately, this issue is not clarified by the Agreement/Joint Communiqué and remains an open one, although the temporary character of the SJP could be (but with no certainty!) inferred from its institutional mission to obtain truth, do away with impunity, contribute to victims' reparations, and to judge, prescribe and lay down sanctions for those allegedly responsible for serious crimes taking place during the armed conflict, and the most serious and representative ones in particular. Again, this is even though the SJP's temporary nature could be considered as implicitly suggested by the SJP's requirements to receive reduced sentences and 'special treatment', provide reparations to victims, and guarantee non-repetition of their acts.

Going on briefly now to recall the way in which the Agreement/Joint Communiqué deals with the problem of drug use, we find that its references to drug use are far too generic, characterized in particular by a failure to differentiate between drug use and abuse (or problem drug utilization), or between different substances as a key element in dealing with the issue. This is despite the fact that some clarity as to the issue of recreational use and abuse of drugs should have been considered as compulsory by the drafters of the Agreement/Joint Communiqué. Again, and more specifically, this is despite the fact that some clarity around this issue would have been of strategic relevance in marking the legal boundaries between drug abuse and addiction.

${ }^{40}$ See Gillian Higgins, above n. 3. 


\section{Concluding Remarks}

There are some hidden lessons to learn from the 2014 Agreement between the FARC and Colombian Government on illicit drugs. One of these is that the initially-agreed purpose of finding 'a definitive solution to the 'problem of illicit drugs' (without even defining it in the Agreement) was naive and simplistic. Yet it is a fact of common experience that, with no exceptions, the problem of illicit drugs cannot be solved, but only managed. Another lesson is that, unlike what was done in the 2014 Agreement, the problem of illicit drugs has to be managed by taking human rights into account in drug control efforts, rather than by criminalizing and punishing drug traffickers ${ }^{41}$.

Still, the above-named Agreement also has some merits, which, far from being 'beyond question', bear some consideration. First, the Agreement is significant in that it proposes a multi-pronged strategy for combating drug (coca) trafficking in Colombia. Essential to this strategy is the emphasis on the eradication of illicit crops. To this end, the Agreement makes a commitment to the state to replace illicit crops and refrain from participating in the trade of raw materials derived from such crops. All producer communities -regardless of whether or not they agree with crop substitution- will have their illicit crops eradicated, with the eradication being carried out either by the communities themselves or by state agencies set up for the purpose. The eradication may even be done by means of aerial spraying. The Agreement further provides for an obligation for the Colombian Government to undertake structural transformation of coca-growing regions through sustainable crop-substitution and alternative development programs. In addition, the Agreement recognizes the need to prioritize efforts to prevent and treat drug consumption. More precisely, it has pledged to create a high-level program to revise and coordinate policies related to drug consumption and to approach the problem as a public health issue rather than a criminal justice issue.

Unfortunately, an examination of the last part of the Agreement reveals the substantial weakness of the commitments by both the Colombian Government and the FARC to end the trafficking of illicit drugs. The Colombian Government has agreed to enforce an integral strategy to stop drug-related corruption by public organizations, end money laundering and create strict new controls against the smuggling of precursor chemicals indispensable for making illegal drugs $^{42}$. The Colombian Government has also agreed to host a conference jointly organized by the United Nations in an effort to attain a universal consensus

${ }^{41}$ Amplius S. Takahashi, International Law and a Human Rights Approach to Drug Control, Oxford: Hart Publishing (forthcoming 2016); El régimen internacional de control de drogas: formación, evolución e interacción con las políticas nacionales. El caso de la política de drogas en España (PhD thesis, Universitat Pompeu Fabra, 2015).

42 See J. Otis, above n. 4. 
on drug policies ${ }^{43}$. For its part, the FARC has agreed 'to put to an end any relation that, in its efforts to promote the rebellion, it may have had with this phenomenon' of drug trafficking ${ }^{44}$.

Finally, international cooperation on drugs issues has been more illusory than real, as appears in particular from the lack of a strategic approach to the issue of drug trafficking, including the seeking of commitments from other countries and guerrilla groups to rethink the present policy on narcotic drugs. 
